\title{
Knowledge of physiotherapists working in adult ICU on contraindications to mobilization
}

\author{
Conhecimento dos fisioterapeutas atuantes em UTI \\ adulto sobre as contraindicações à mobilização
}

\author{
Amina Maria Soares de Lima $(\mathbb{D}$, Daniella Cunha Brandão $\mathbb{D}$, Carlos Eduardo Santos Rego Barros $\mathbb{D}$, Maria \\ Karoline de França Richtrmoc $\mathbb{D}^{\mathbb{D}}$, Armèle de Fátima Dornelas de Andrade $\mathbb{D}$, Shirley Lima Campos $\mathbb{D} *$
}

Universidade Federal de Pernambuco (UFPE), Recife, PE, Brazil

\begin{abstract}
Introduction: Mobilization is an effective therapy to combat the deleterious effects of immobility, but not all patients are in a condition to be moved; thus, knowledge about contraindication criteria is fundamental. Objective: To evaluate the knowledge of physiotherapists working in adult ICUs on contraindications to the mobilization of critical patients. Method: This was a cross-sectional study in which a survey was applied to physiotherapists working in an adult ICU in the city of Recife. Results: Out of the 36 criteria presented, only five were considered contraindication criteria. Clinical parameters were those that obtained higher frequency for not being considered criteria for contraindication, nor were there observed differences in the relation between the time of working in the ICU. Conclusion: Most physiotherapists did not consider the criteria presented as contraindications to mobilization, so that professional training in mobilization practices and the creation of protocols are necessary.
\end{abstract}

Keywords: Rehabilitation. Intensive Care Unit. Exercise.

\footnotetext{
*AMSL: MS, e-mail: amina_lima@hotmail.com DCB: PhD, e-mail : daniellacunha@hotmail.com CESRB: MS, e-mail: carlosregobarros@hotmail.com MKFR: MS, e-mail: karolrichtrmoc@yahoo.com AFDA: PhD, e-mail: armeledornelas@yahoo.com SLC: PhD, e-mail: shirleylcampos@uol.com.br
} 
Resumo

Introdução: A mobilização é uma terapia eficaz para combater os efeitos deletérios do imobilismo, contudo, é sabido que nem todos os pacientes apresentam condições de saúde para recebê-la, sendo assim, é fundamental o conhecimento sobre os critérios de contraindicação. Objetivo: Avaliar o conhecimento dos fisioterapeutas atuantes em UTI adulto sobre as contraindicações à mobilização de pacientes críticos na cidade do Recife. Método: Este é um estudo transversal, no qual foi aplicado um inquérito aos fisioterapeutas atuantes em UTI adulto na cidade do Recife. Resultados: Dos 36 critérios expostos, apenas cinco foram considerados critérios de contraindicação. Os parâmetros clínicos foram os que obtiveram maior frequência como não sendo considerados critérios de contraindicação, também não foram observadas diferenças na relação entre grau acadêmico e o conhecimento dos critérios, assim como no tempo de atuação em UTI. Conclusão: Uma proporção significativa dos fisioterapeutas atuantes em UTI não considera os critérios expostos como contraindicações à prática da mobilização, sendo assim necessário o aperfeiçoamento profissional sobre as práticas da mobilização e a criação de protocolos.

Palavras-chave: Reabilitação. Unidade de Terapia Intensiva. Exercício.

\section{Introduction}

The immobility observed in most critical patients is responsible for the increase in the length of hospital stay and weaning from mechanical ventilation and for the reduction in functionality and quality of life [1- 6]. In addition there is a negative effect on the economy of health systems, through prolonged hospital stay and spending on retirements and pensions [7, 8].

As a result of the aforementioned damages, several studies $[1,7,9-12]$ have shown that mobilization is a safe and effective intervention to combat the effects of immobility $[13,14]$, providing benefits such as reducing muscle weakness and improving quality of life [1, 15-17].

Despite being a technique with rare adverse events [9, 16-21], the mobilization of critically ill patients should be carried out with caution, since the literature points that there are parameters of contraindication of respiratory, cardiovascular, neurological, traumaorthopedic, hematological and clinical nature $[1,3$, 6, 22-26].

However, although these criteria are generally similar, it is possible to observe the existence of some divergences, mainly in relation to the reference values of some parameters, such as hemoglobin level, white blood cells, platelets, respiratory rate (RR), heart rate (HR), oxygen saturation $\left(\mathrm{SpO}_{2}\right)$ and mean arterial pressure (MAP) $[1,6,7,22-26]$. Therefore, decision-making for mobilization in critically ill patients must consider the physiotherapist's knowledge of these criteria.

Accordingly, the objectives of this study were: 1) to outline the profile of physical therapists working in the adult ICUs in public and private hospitals in the city of Recife in Brazil; 2) to evaluate the knowledge of these professionals about the application of contraindication criteria for patient mobilization in making clinical decisions; and 3) to analyze the influence of the time working in the ICU on acquiring knowledge of these criteria.

\section{Method}

We conducted a cross-sectional survey type study, which was approved by the Ethics and Research Committee Involving Human Beings (CEP) of the Center for Health Sciences, Federal University of Pernambuco (UFPE), under CAAE No. 15019113.7.0000.5208, according to Resolution 466/12.

The population consisted of physiotherapists working in an adult ICU of public and private hospitals in the city of Recife. Units listed in the National Register of Health Establishments - CNES were visited through the website (http://cnes2.datasus.gov.br/) in 2016, 
where 39 hospitals had been registered, of which three had closed and nine were excluded due to bureaucratic obstacles.

A total of 410 professionals were included in the study according to information collected from the heads of the respective services, where the appropriate number of questionnaires was sent. The collections took place from March 2016 to February 2017.

For inclusion of the professional in the study, a record was registered with the Regional Physiotherapy Council (CREFITO) and an account of working in an adult ICU in public and private hospitals in Recife. The duplications were checked by the board's registration number.

Data collection occurred with the consent to access the service, where the physical therapists were directly approached. Those who voluntarily agreed to participate signed an informed consent form and then responded without assistance with the questionnaire.

For the elaboration of the survey, a search was performed in the electronic databases PubMed, Lilacs and Scielo using the keywords: early mobilization, rehabilitation, ICU and exercise to list the criteria for contraindication to mobilization. Subsequently, systematic meetings were held with experts in the field for the preparation of the list of criteria, and a pilot study was carried out with 20 physical therapists specialized in working in the ICU for suitability of language and conciseness, to fix inconsistencies, complexities, ambiguities and superfluous questions.

The final questionnaire was self-explanatory and was provided with instructions necessary for its correct completion, without the need for an examiner. It consisted of four parts: 1) academic training and professional data; 2) professional practice; 3) profile of the ICU at which working; and 4) list of criteria for contraindication to mobilization.

The statistical analysis was performed using the software Statistical Package for the Social Sciences, (SPSS), Chicago, version 20.0, where the absolute and relative frequencies were calculated for the categorical variables. The number of responses "not a criterion" (considered "error") was analyzed using a t-test for proportions [H0: $p=0]$, thus observing whether the proportion of the response "not a criterion" was significant in the sample as whole. From this analysis, when $\mathrm{p}<0.05(\alpha=0.05)$ was obtained, there was a significant proportion of professionals who did not consider a certain criterion to be a contraindication, when compared to the professionals who did. For this analysis, it was not taken into account whether the contraindication was absolute or relative, nor were the responses "I don't know" analyzed.

The chi-square test was also performed to determine the association between length of experience and the contraindication criteria. For this calculation, the length of service was divided into two groups, up to five years of experience and more than five years, due to the distribution of professionals in these ranges.

\section{Results}

We obtained a response rate of 39.5\%, making it possible to characterize the profile and practice of physiotherapists. The data are presented in Table 1.

Table 1 - Sample characterization and data on professional practice

\begin{tabular}{llcc}
\hline Variable & & N & \% \\
\hline Working in some other area & Yes & 96 & 59.3 \\
besides adult ICU & No & 66 & 40.7 \\
& Graduation & 12 & 7.4 \\
& Specialization in ICU & 99 & 61.1 \\
Academic level & Another specialization & 47 & 29 \\
& Master's & 3 & 1.85 \\
& Ph.D & 1 & 0.6 \\
Profile of current ICU & General & 95 & 58.4 \\
& Neurology & 14 & 8.6 \\
Cardiology & Traumatology & 46 & 28.4 \\
& Hematology & 1 & 0.6 \\
& Yes & 6 & 3.7
\end{tabular}




\begin{tabular}{lccc} 
Existence of mobilization & Yes & 81 & 50 \\
protocol & No & 81 & 50 \\
Existence of protocol & Yes & 74 & 45.7 \\
for contraindication to & No & 88 & 54.3 \\
mobilization & Yes & 114 & 73.5 \\
Existence of protocol for & No & 43 & 26.5 \\
interruption of sedation & Yes & 154 & 95.1 \\
Mobilization of sedated & No & 8 & 4.9 \\
patients & Yes & 149 & 92 \\
Mobilization of patients using & No & 13 & 8 \\
VAD & Yes & 48 & 29.6 \\
Physiotherapist is the only & No & 114 & 70.4 \\
one to evaluate the patient for & Yes & 65 & 40.1 \\
mobilization & No & 97 & 59.9 \\
Physiotherapist receives help & Yes & 86 & 53.1 \\
from other professionals for & No & 76 & 46.9 \\
mobilization & & & \\
Occurrence of undesirable & event & & \\
\hline
\end{tabular}

The physiotherapists' knowledge of contraindication criteria and of parameters most considered as not being an impediment to mobilization, can be seen in numbers and frequencies in Table 2 and Figure 1, respectively.
Figure 1 shows that when separated into groups, the criteria that were reported most often as not being considered a contraindication to mobilization were clinical parameters.

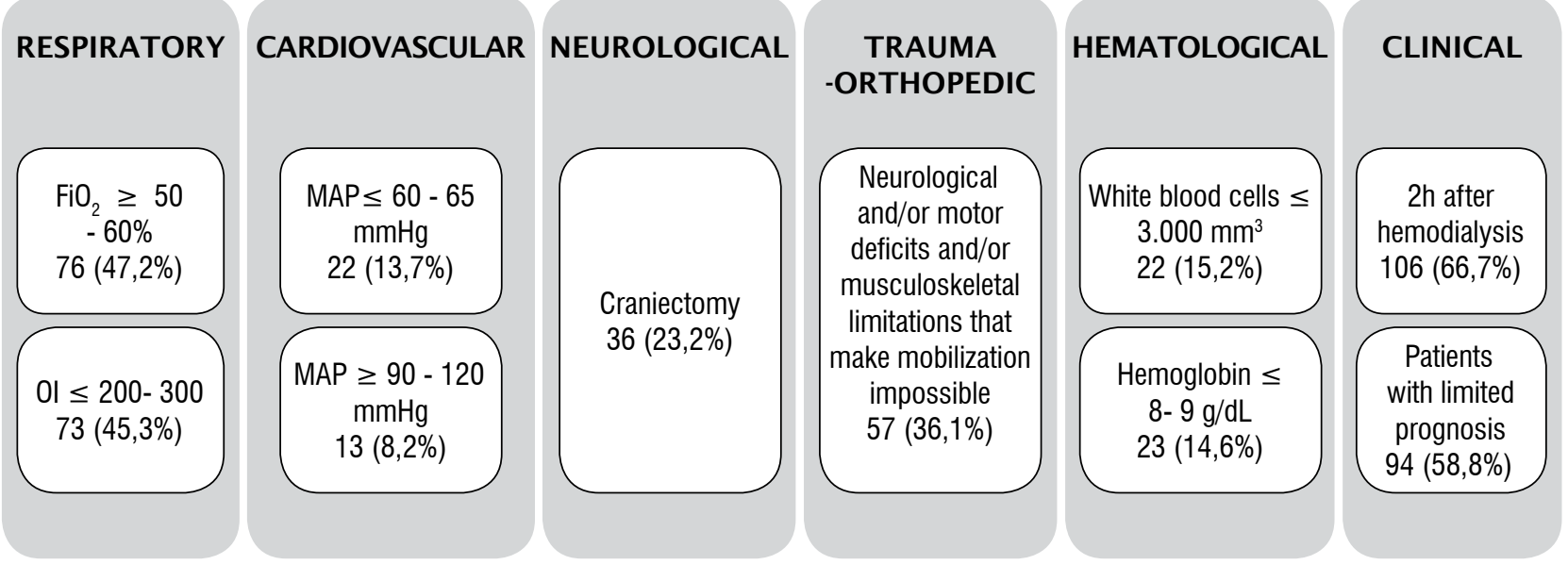

Figure 1 - Criteria more often considered as not being a contraindication. Note: ${ }^{*} \mathrm{FiO}_{2}$ - fraction of inspired oxygen, $\mathrm{Ol}$ - oxygenation index, MAP- mean arterial pressure.

Table 2 - General characteristics of children and adolescents with cystic fibrosis according to the frequency of physical activity

\begin{tabular}{lcccc}
\hline $\begin{array}{l}\text { Contraindication } \\
\text { Criteria }\end{array}$ & $\begin{array}{c}\text { Major criterion } \\
\text { (Absolute) } \\
\mathbf{n} \text { (\%) }\end{array}$ & $\begin{array}{c}\text { Minor criterion } \\
\text { (Relative) } \\
\mathbf{n} \text { (\%) }\end{array}$ & Not a criterion & P \\
\hline Respiratory & & & & \\
$\mathrm{FiO}_{2} \geq 50-60 \%$ & $(15) 9.3 \%$ & $(70) 43.2 \%$ & $(76) 46.9 \%$ & 0.01 \\
$\mathrm{SpO}_{2} \leq 88-90 \%$ & $(26) 16 \%$ & $(103) 63.6 \%$ & $(31) 19.1 \%$ & 0.01 \\
$0 \mathrm{I} \leq 200-300$ & $(15) 9.3 \%$ & $(73) 45.1 \%$ & $(73) 45.1 \%$ & 0.01 \\
$\mathrm{RR} \leq 25$ and $\geq 40$ breaths/min & $(40) 24.7 \%$ & $(99) 61.1 \%$ & $(23) 14.2 \%$ & 0.01 \\
$\mathrm{PEEP} \geq 10 \mathrm{CmH}_{2} \mathrm{O}$ & $(26) 16 \%$ & $(72) 44.4 \%$ & $(64) 39.5 \%$ & 0.01 \\
Asynchronous ventilation & $(51) 31.5 \%$ & $(74) 45.7 \%$ & $(35) 21.6 \%$ & 0.01
\end{tabular}




\section{Cardiovascular}

Arrhythmias with hemodynamic repercussion

(145) $89.5 \%$

(17) $10.5 \%$

Thromboembolism without

heparinization

(151) $93.2 \%$

(10) $6.2 \%$

Signs of hemorrhage

(144) $88.9 \%$

(17) $10.5 \%$

$\mathrm{HR} \leq 30$ and $\geq 120 \mathrm{bpm}$

(115) $71 \%$

(46) $28.4 \%$

MAP $\leq 60-65 \mathrm{mmHg}$

(88) $54.3 \%$

$\mathrm{MAP} \geq 90-120 \mathrm{mmHg}$

(51) $31.5 \%$

(105) $64.8 \%$

(1) $0.6 \%$

0.319

(41) $25.3 \%$

(22) $13.6 \%$

0.01

Neurological

ICP $\geq 20 \mathrm{mmHg}$

(124) $76.5 \%$

(26) $16 \%$

(13) $8 \%$

0.01

Craniectomy

(27) $1.6 \%$

(92) $56.8 \%$

(7) $4.3 \%$

0.008

(115) $71 \%$

(39) $24.1 \%$

(36) $22.2 \%$

0.01

(68) $42 \%$

(73) $45 \%$

(5) $3.1 \%$

0.025

Psychiatric disorders or severe

agitation

(16) $9.9 \%$

0.01

Trauma -orthopedic

Trauma or surgery of the leg, hip or lumbar spine

(17) $10.5 \%$

(102) $63 \%$

(40) $24.7 \%$

0.01

Unconsolidated hip or lower limb fractures

(67) $41.4 \%$

(78) $48.1 \%$

(15) $9.3 \%$

0.01

Neurological and/or motor deficits and/or musculoskeletal limitations that make mobilization impossible

(29) $17.9 \%$

(72) $44.4 \%$

(57) $35.2 \%$

0.01

Contraindications to muscle

stretching

(37) $22.8 \%$

(81) $50 \%$

(36) $22.2 \%$

0.01

Hematological

Platelets $\leq 20,000-50,000 \mathrm{~mm}^{3}$

(76) $46.9 \%$

(75) $46.3 \%$

(7) $4.3 \%$

0.008

White bloodcells $\leq 3,000 \mathrm{~mm}^{3}$

(45) $27.8 \%$

(78) $48.1 \%$

(22) $13.6 \%$

0.01

Hemoglobin $\leq 8-9 \mathrm{~g} / \mathrm{dL}$

(38) $23.5 \%$

(97) $59.6 \%$

(23) $14.2 \%$

0.01

\section{Clinical}

On day of and $24 \mathrm{~h}$ after

radiotherapy

(19) $11.7 \%$

(78) $48.1 \%$

(26) $16 \%$

0.01

Advanced cancer with metastases

(23) $14.2 \%$

(90) $55.6 \%$

(42) $25.9 \%$

0.01

Immunosuppressive potential

(60) $37 \%$

(62) $38 \%$

(8) $4.9 \%$

0.004

Open abdominal wounds

Severe liver disease with

thrombocytopenia

(32) $19.8 \%$

(97) $59.9 \%$

(30) $18.5 \%$

0.01

(105) $64.8 \%$

(47) $29 \%$

(8) $4.9 \%$

0.004

Severe sores or venous ulcers

Hypothermia $\leq 34^{\circ} \mathrm{C}$ or fever $\geq$ $38^{\circ} \mathrm{C}$

(19) $11.7 \%$

(91) $56.2 \%$

(51) $31.5 \%$

0.01

(104) $64.2 \%$

(54) $33.3 \%$

(2) $1.2 \%$

0.158

General malaise

(44) $27.2 \%$

(103) $63.6 \%$

(14) $8.6 \%$

0.01

Severecachexia and dehydration

(42) $25.9 \%$

(81) $50 \%$

(31) $19.1 \%$

0.01

Bone, muscle and chest pain

(27) $16.7 \%$

(108) $66.7 \%$

(85) $15.4 \%$

0.01

$2 \mathrm{~h}$ afterhemodialysis

(9) $5.6 \%$

(44) $27.2 \%$

(106) $65.4 \%$

0.01

Patients with limited prognosis

(3) $1.9 \%$

(63) $38.9 \%$

(94) $58 \%$

0.01

Note: $\mathrm{FiO}_{2}=$ fraction of inspired oxygen, $\mathrm{Ol}=$ oxygenation index, MAP $=$ mean blood pressure, PEEP $=$ positive end expiratory pressure, ICP $=$ intracranial pressure. * $t$-test for the proportion of the sample answering "not a criterion", removing those who answered "I don't know". [HO: $p=0$ ]. 
The association between length of service and the parameters, namely: craniectomy and intracranial pressure criteria showed a significant result for two of the $36 \geq 20 \mathrm{mmHg}$. These data can be seen in detail in Table 3 .

Table 3 - Association between time working in the ICU and criteria for contraindication to mobilization

\begin{tabular}{|c|c|c|c|c|c|}
\hline \multirow{2}{*}{$\begin{array}{l}\text { Contraindication } \\
\text { criteria }\end{array}$} & \multicolumn{2}{|c|}{ Up to 5 years } & \multicolumn{2}{|c|}{ More than 5 years } & \multirow[t]{2}{*}{$P$} \\
\hline & Correction & Error & Correction & Error & \\
\hline \multicolumn{6}{|l|}{ Respiratory } \\
\hline $\mathrm{FiO}_{2} \geq 50-60 \%$ & $48(56.5)$ & $37(43.5)$ & $37(48.7)$ & $39(51.3)$ & 0.325 \\
\hline $\mathrm{SpO}_{2} \leq 88-90 \%$ & $82.2 \pm 12.6$ & $17(20.2)$ & $62(81.6)$ & $14(18.4)$ & 0.772 \\
\hline $0 \mathrm{l} \leq 200-300$ & $84.7 \pm 19.2$ & 38 (45.2) & $42(54.5)$ & $35(45.5)$ & 0.978 \\
\hline $\mathrm{RR} \leq 25$ and $\geq 40 \mathrm{bpm}$ & $75.7 \pm 20.6$ & $12(14.1)$ & $66(85.7)$ & $11(14.3)$ & 0.976 \\
\hline PEEP $\geq 10 \mathrm{~cm} \mathrm{H}_{2} 0$ & $73.6 \pm 20.1$ & $37(43.5)$ & $50(64.9)$ & $27(35.1)$ & 0.273 \\
\hline Asynchronous ventilation & $83 \pm 25.2$ & $14(16.9)$ & $56(72.7)$ & $21(27.3)$ & 0.113 \\
\hline \multicolumn{6}{|l|}{ Cardiovascular } \\
\hline Arrhythmias & $85(100)$ & 0 & $77(100)$ & 0 & - \\
\hline $\begin{array}{l}\text { Thromboembolism without } \\
\text { heparinization }\end{array}$ & $85(100)$ & 0 & $76(100)$ & 0 & - \\
\hline Signs of hemorrhage & $85(100)$ & 0 & $76(98.7)$ & $1(1.3)$ & 0.293 \\
\hline $\mathrm{HR} \leq 30$ and $\geq 120 \mathrm{bpm}$ & $84(100)$ & 0 & $77(100)$ & 0 & - \\
\hline $\mathrm{MAP} \leq 60-65 \mathrm{mmHg}$ & $74(87.1)$ & $11(12.9)$ & $65(85.5)$ & $11(14.5)$ & 0.778 \\
\hline MAP $\geq 90-120 \mathrm{mmHg}$ & 78 (92.9) & $6(7.1)$ & $68(90.7)$ & $7(9.3)$ & 0.616 \\
\hline $\begin{array}{l}\text { Neurological } \\
\text { Intracranial pressure } \geq 20 \\
\mathrm{mmHg}\end{array}$ & $83(100)$ & 0 & $67(90.5)$ & $7(9.5)$ & 0.004 \\
\hline Craniectomy & $55(68.8)$ & $25(31.2)$ & $64(85.3)$ & $11(14.7)$ & 0.015 \\
\hline Unstable spinal fractures & $80(97.6)$ & $2(2.4)$ & $74(96.1)$ & $3(3.9)$ & 0.600 \\
\hline $\begin{array}{l}\text { Psychiatric disorders or } \\
\text { severe agitation }\end{array}$ & 77 (93.9) & $5(6.1)$ & $64(85.3)$ & $64(85.3)$ & 0.077 \\
\hline \multicolumn{6}{|l|}{ Trauma-Orthopedic } \\
\hline $\begin{array}{l}\text { Trauma or surgery of leg, } \\
\text { hip or lumbar spine }\end{array}$ & $66(80.5)$ & $16(19.5)$ & $53(68.8)$ & $24(31.2)$ & 0.092 \\
\hline $\begin{array}{l}\text { Unconsolidated hip or lower } \\
\text { limb fractures } \\
\text { Neurological and/or } \\
\text { motor deficits and/or }\end{array}$ & $78(94)$ & $5(6)$ & $67(87)$ & $10(13)$ & 0.092 \\
\hline $\begin{array}{l}\text { musculoskeletal limitations } \\
\text { that make mobilization } \\
\text { impossible }\end{array}$ & $50(61)$ & $32(39)$ & $51(67.1)$ & $25(32.9)$ & 0.424 \\
\hline $\begin{array}{l}\text { Contraindications to muscle } \\
\text { stretching }\end{array}$ & $63(79.7)$ & $16(20.3)$ & $55(73.3)$ & $20(26.7)$ & 0.349 \\
\hline \multicolumn{6}{|l|}{ Hematological } \\
\hline $\begin{array}{l}\text { Platelets } \leq 20,000- \\
50,000 \mathrm{~mm}^{3}\end{array}$ & $79(95.2)$ & $4(4.8)$ & $72(96)$ & $3(4)$ & 0.803 \\
\hline $\begin{array}{l}\text { White bloodcells } \leq 3,000 \\
\mathrm{~mm}^{3}\end{array}$ & $66(86.8)$ & $10(13.2)$ & $57(82.6)$ & $12(17.4)$ & 0.479 \\
\hline Hemoglobin $\leq 8-9 \mathrm{~g} / \mathrm{dL}$ & $73(86.9)$ & $11(13.1)$ & $62(83.8)$ & $12(16.2)$ & 0.580 \\
\hline
\end{tabular}




\begin{tabular}{lccccc}
$\begin{array}{l}\text { On day of and } 24 \mathrm{~h} \text { after } \\
\text { radio therapy }\end{array}$ & $52(80)$ & $13(20)$ & $45(77.6)$ & $13(22.4)$ & 0.744 \\
$\begin{array}{l}\text { Advanced cancer with } \\
\text { metastases }\end{array}$ & $59(72)$ & $23(28)$ & $54(74)$ & $19(26)$ & 0.778 \\
$\begin{array}{l}\text { Immunosuppressive } \\
\text { potential }\end{array}$ & $65(91.5)$ & $6(8.5)$ & $57(96.6)$ & $2(3.4)$ & 0.234 \\
$\begin{array}{l}\text { Open abdominal wounds } \\
\begin{array}{l}\text { Severe liver disease with } \\
\text { thrombocytopenia }\end{array}\end{array}$ & $70(84.3)$ & $13(15.7)$ & $59(77.6)$ & $17(22.4)$ & 0.282 \\
$\begin{array}{l}\text { Severe sores or venous } \\
\text { ulcers }\end{array}$ & $79(95.2)$ & $4(4.8)$ & $73(94.8)$ & $4(5.2)$ & 0.914 \\
$\begin{array}{l}\text { Hypothermia } \leq 34^{\circ} \mathrm{C} \text { or } \\
\text { fever } \geq 38^{\circ} \mathrm{C}\end{array}$ & $59(70.2)$ & $25(29.8)$ & $51(66.2)$ & $26(33.8)$ & 0.587 \\
$\begin{array}{l}\text { General malaise } \\
\text { Severecachexia and }\end{array}$ & $82(98.8)$ & $1(1.2)$ & $76(98.7)$ & $1(1.3)$ & 0.958 \\
$\begin{array}{l}\text { dehydration } \\
\text { Bone, muscle or chest pain }\end{array}$ & $65(92.9)$ & $6(7.1)$ & $69(89.6)$ & $8(10.4)$ & 0.467 \\
$\begin{array}{l}\text { Pain } \\
\text { 2h afterhemodialysis }\end{array}$ & $68(81)$ & $16(19)$ & $67(88.2)$ & $9(11.8)$ & 0.903 \\
$\begin{array}{l}\text { Patients with limited } \\
\text { prognosis }\end{array}$ & $25(30.1)$ & $58(69.9)$ & $28(36.8)$ & $48(63.2)$ & 0.211 \\
\hline
\end{tabular}

Note: $\mathrm{Fi}_{2}=$ fraction of inspired oxygen, $\mathrm{Ol}=$ oxygenation index, $\mathrm{PEEP}=$ positive end expiratory pressure, $\mathrm{PAM}=$ mean arterial pressure, ICP = intracranial pressure.Chi-square test between the variables contraindication criteria and time working in the ICU, with the sample being divided into two groups: up to five years of experience and greater than five years.

\section{Discussion}

The data obtained in our study show that an important proportion of the sample of physiotherapy professionals working in an adult ICU in the city of Recife did not consider 31 of the 36 criteria considered as a contraindication, the most frequently disregarded criteria were the clinical parameters: two hours after hemodialysis and patients with limited prognosis. Also, the length of experience in the ICU did not significantly influence the majority of the physiotherapists' responses.

\section{Physiotherapists' profile}

The response rate of $39.5 \%$ obtained in this study is similar to that found in the study by Nozawa et al. [27], with a $30 \%$ return of the questionnaires sent to all Brazil, a percentage adequate enough to determine the profile of physiotherapists working in the ICU.

According to Table 1, of the 162 physiotherapists, $59.3 \%$ worked in another area besides the adult ICU, the experience time observed was between 5 and 10 years,
$58.6 \%$ worked in a general ICU and $61.1 \%$ specialized in intensive care. These findings are in line with those found by Nozawa et al. [27], when they determined this professional profile throughout Brazil. Different profiles were found in the studies by Bhat et al. [28] and Hale et al. [29]. The first conducted in India, showed that more than half of its respondents had just graduated; however, $34 \%$ said they had a master's degree, almost 18 times the number found in our study. In the second study, carried out with Canadian physiotherapists, it was observed that most of the interviewees in their research did not have a high academic degree, but they reported relying on the scientific literature to practice mobilization [29].

Regarding the help of the multidisciplinary team during the mobilization and evaluation of the critical patient, about $60 \%$ of the physical therapists who participated in the study stated that they performed the mobilization alone. This fact can be explained by the fulfillment of resolution No. 402 of August 3, 2011, Article 
3, paragraphs II, VI, VII, VIII, X and XII, which briefly state that the physiotherapist is responsible for evaluating, prescribing and carrying out the rehabilitation of critical patients but that the multidisciplinary team's assistance is essential for a differentiated assessment and safe mobilization [17, 28-31].

Approximately $77 \%$ of physical therapists reported that there was a protocol for daily interruption of sedation in the hospitals where they worked. Compliance with this protocol is essential, since the inappropriate use of sedatives impairs the patient's participation during exercise, in addition to contributing to the increase in the time of weaning from mechanical ventilation and the onset of episodes of delirium [32-37].

There is no consensus among professionals and the literature on the safe dose for vasoactive drugs, with different values ranging between 0.1 and $10 \mathrm{mcg} / \mathrm{kg} /$ min for noradrenaline, for example [17, 21, 38, 39]. An increased in dose in the last 2 to $4 \mathrm{~h}$ [40-42] or even just the existence of a vasopressor is already considered a contraindication criterion in some studies $[17,43]$ even if the patient is hemodynamically stable [44].

Undesirable events occurred with $53.1 \%$ of the physiotherapists despite the fact that they reported interrupting the exercise in the appearance of most of the criteria found in the literature $[1,11,25,45]$. The most frequently reported event was hypotension. Green et al. [30] for 10 years recorded two episodes of hypotension during their mobilization protocol [30]. The frequency of occurrence of these events can be explained by the absence of protocols for mobilization and contraindication in a considerable part of the services, impairing the safety and benefits of the procedure $[17,30,35,46]$.

\section{Physiotherapist's knowledge of contraindication criteria in ICU}

In Table 3, it can be seen that a substantial proportion of the sample did not consider 31 of the 36 criteria considered, as a contraindication, except for: arrhythmias with hemodynamic repercussions, thromboembolism without heparinization, signs of hemorrhage, $\mathrm{HR} \leq 30$ and $\geq 120 \mathrm{bpm}$ and hypothermia $\leq 34^{\circ} \mathrm{C}$ or fever $\geq 38^{\circ} \mathrm{C}$. Although no similar study was found in the databases searched, we can raise the hypothesis described below.

The options "criterion of major/absolute contraindication" and "criterion of minor/relative contraindication" were included in this survey, since we considered them as usual terms used in clinical practice for decision-making [23]. Although our study did not differentiate the absolute and relative criteria for statistical analysis, we observed in a descriptive way, the existence of a fine line between the answers "minor/relative contraindication criterion" and "not a contraindication criterion." Knowing that all the parameters queried are contraindications to mobilization according to the literature, the fact that there was no differentiation between what would be an absolute or relative criterion, along with the nonuniformity of evidence on the parameters for most of these criteria, may explain our findings.

The criteria with the highest frequency of "I don't know" responses were "immunosuppressive potential" and "on day of and $24 \mathrm{~h}$ after radiotherapy". Patients in this state are generally fragile and debilitated, and depending on the intensity of the exercise, there may be too much increase in metabolic demand, reducing the body's ability to recover $[47,48]$. Included in the class of "clinical" parameters, we can infer that these criteria have a greater subjective characteristic, which can hinder the applicability of these parameters.

The parameters illustrated in Figure 1 present the criteria most often considered as not being contraindicated by physical therapists, not being in accordance with literature findings $[23,36,49]$, and they are separated by groups:

$\mathrm{FiO}_{2} \geq 50-60 \%$ and $\mathrm{OI} \leq 200-300$ : ventilatory demand increases during exercise $[44,49]$ predisposing to a fall in $\mathrm{SpO}_{2}$, usually resolved by an increase in $\mathrm{FiO}_{2}$. Fractions between 50 and $60 \%$ are considered high, representing a relative risk to the patient $[23,25]$. The OI translates important aspects of the respiratory reserve, an OI of 200-300 is considered borderline, and depending on the intensity of the exercise, it can lead to a drop in oxygen saturation and dyspnea [50].

$\mathrm{MAP} \leq 60-65 \mathrm{mmHg}$ and MAP $\geq 90-120 \mathrm{mmHg}$ : the blood pressure of critically ill patients varies rapidly during exercise, but there are no absolute values considered safe, so it is necessary to observe the use of vasoactive drugs and monitor hemodynamic changes [50].

Craniectomy: it is a surgical procedure generally used to prevent damage to nerve tissues $[50,51]$. Hodgson et al. [23] considers craniectomy as a relative contraindication when exercises are performed out of bed.

Neurological and/or motor deficits and/or musculoskeletal limitations that make mobilization impossible: they constitute contraindications in 
several studies, since they make it impossible to carry out the mobilization protocols, whether in performing exercises, positioning or using equipment such as a cycle ergometer [10, 36, 41, 49, 50, 52-57].

Hemoglobin $\leq 8-9 \mathrm{~g} / \mathrm{dL}$ and white blood cells $\leq 3,000$ $\mathrm{mm}^{3}$ : the function of hemoglobin is to oxygenate the tissues [58], and low concentrations favor symptoms such as muscle fatigue and dyspnea, impairing exercise $[50,58]$. White blood cells suggest the presence of infections, which tend to increase oxygen demand, which can make exercise an exhausting and organic overload situation [50].

Two hours after hemodialysis and patients with limited prognosis: exercise is recommended during the first two hours after dialysis, since the appearance of hemodynamic instability is common after dialysis [59-61]. Patients with limited prognosis are defined as patients with no possibility of medical cure, and can be under palliative care, which aims at general well-being, and exercise can be a tool for the relief of pain, stress and depression [62].

Influence of time of working in the ICU to retain knowledge of contraindication criteria

When comparing the time of experience in the ICU and the contraindication criteria, no significant difference was found between those who had worked for five years or less and those who had longer experience. However, Hoyer et al. [63] in interviewing 120 professionals working in the ICU (including nurses, doctors, physiotherapists and occupational therapists) showed that less experienced professionals had more difficulties in carrying out mobilization. Thus, the comparison with our findings was flawed, since each class had its particularities.

\section{Conclusion}

A substantial proportion of the physiotherapists interviewed did not consider most literature findings as contraindications, with the parameters most often not considered as contraindications being: $\mathrm{FiO}_{2} \geq 50-60 \%$, $\mathrm{OI} \leq 200-300$; $\mathrm{MAP} \leq 60$ - 65 mmHg; MAP > $90-120$ $\mathrm{mmHg}$; craniectomy; neurological and/or motor deficits and/or musculoskeletal limitations that make mobilization impossible; hemoglobin $\leq 8-9 \mathrm{~g} / \mathrm{dL}$; white blood cells $\leq 3,000 \mathrm{~mm}^{3}$; two hours after hemodialysis and patients with limited prognosis. In addition, training time did not seem to influence the response pattern of these physiotherapists.

However, this study had some limitations, including: bureaucratic obstacles; absence of data from all hospitals in the region under study; non-differentiation of absolute and relative criteria in statistical analysis and subjectivity of some criteria in the preparation of the questionnaire. Therefore, more nationwide studies are needed to elaborate which contraindication criteria are considered as a consensus among physiotherapists to support the clinical practice of these professionals.

However, despite the limitations found, the results presented are important, as there are no similar studies that show the divergences between the knowledge of physiotherapists and the literature findings on the mobilization of critical patients. Thus, it can be concluded that there is a need to improve the knowledge of physiotherapists about

\section{References}

1. Burtin C, Clerckx B, Robbeets C, Ferdinande P, Langer D, Troosters T, et al. Early exercise in critically ill patients enhances short-term functional recovery. Crit Care Med. 2009;37(9):2499-505.

2. Gosselink R, Clerckx B, Robbeets C, Vanhullebusch T, Vanpee G, Segers J. Physiotherapy in the Intensive Care Unit. Netherlands J Crit care. 2011;15(2).

3. Nordon-Craft A, Moss M, Quan D, Schenkman M. Intensive care unit-acquired weakness: implications for physical therapistmanagement. Phys Ther. 2012; 92(12):1494-506.

4. Ramsay P, Salisbury LG, Merriweather JL, Huby G, Rattray JE, Hull AM, et al. A rehabilitation intervention to promote physical recovery following intensive care: a detailed description of construct development, rationale and content together with proposed taxonomy to capture processes in a randomised controlled trial. Trials. 2014;15:38.

5. Miller MA, Govindan S, Watson SR, Hyzy RC, Iwashyna TJ. ABCDE, but in that order? A cross-sectional survey of Michigan intensive care unit sedation, delirium, and early mobility practices. Ann AmThorac Soc. 2015;12(7):1066-71. 
6. Mota CM, Silva VG. A segurança da mobilização precoce em pacientes críticos: uma revisão de literatura. Interfaces Cient Saude Ambiente. 2012;1(1):83-91.

7. Brahmbhatt N, Murugan R, Milbrandt EB, Deprizio D, Ga S, Bowman A, et al. Early mobilization improves functional outcomes in critically ill patients. Crit Care. 2010;321(14):2-4.

8. Nelson JE, Cox CE, Hope AA, Carson SS. Chronic critical illness. Am J Respir Crit Care Med. 2010;182(4):446-54.

9. Truong A, Fan E, Brower R, Needham D. Bench-to-bedside review: Mobilizing patients in the intensive care unit-from pathophysiology to clinical trials. Crit Care. 2009;13(4):216.

10. Angelopoulos E, Karatzanos E, Dimopoulos S, Mitsiou G, Stefanou C, Patsaki I, etal. Acute microcirculatory effects of medium frequency versus high frequency neuromuscular electrical stimulation in critically ill patients - a pilot study. Ann Intensive Care. 2013;3(1):39.

11. Morris PE, Goad A, Thompson C, Taylor K, Harry B, Passmore L, et al. Early intensive care unit mobility therapy in the treatment of acute respiratory failure. Crit Care Med. 2008;36(8):2238-43.

12. Wieske L, Witteveen E, Verhamme C, Dettling-Ihnenfeldt DS, van der Schaaf M, Schultz MJ, et al. Early prediction of intensive care unit-acquired weakness using easily available parameters: A prospective observational study. PLoS One. 2014;9(10):e111259.

13. Wollersheim T, Haas K, Wolf S, Mai K, Spies C, SteinhagenThiessen E, etal. Whole-body vibration to prevent intensive care unit-acquired weakness: safety, feasibility, and metabolic response. Crit Care. Critical Care; 2017;21:1-10.

14. Govindan S, Iwashyna TJ, Odden A, Scott A, Chopra V, Arbor A, etal. Mobilization in severe sepses: An integrative review. J Hospmedice. 2016;10(1):54-9.

15. Clark DE, Lowman JD, Griffin RL, Matthews HM, Reiff DA. Effectiveness of an early mobilization protocol in a trauma and burns intensive care unit: a retrospective cohort study. Phys Ther. 2013;93(2):186-96.

16. Hodgson CL, Berney S, Harrold M, Saxena M. Clinical review: Early patient mobilization in the ICU. Crit Care. 2013;17(1):207.

17. Hickmann CE, Castanares-Zapatero D, Bialais E, Dugernier J, Tordeur A, Colmant L, etal. Teamwork enables high level of early mobilization in critically ill patients. Ann Intensive Care. 2016;6(1):80.
18. Perme C, Nawa RK, Winkelman C, Masud F. A tool to assess mobility status in critically ill patients: the Perme Intensive Care Unit Mobility Score. Methodist Debakey Cardiovasc J. 2014;10(1):41-9.

19. Kho ME, Molloy AJ, Clarke F, Herridge MS, Koo KKY, Rudkowski J, et al. CYCLE pilot: a protocol for a pilot randomised study of early cycle ergometry versus routine physiotherapy in mechanically ventilated patients. BMJ Open. 2016;6(4):e011659.

20. Leditschke IA, Green M, Irvine J, Bissett B, Mitchell IA. What Are the Barriers to Mobilizing Intensive Care Patients? Cardiopulm Phys Ther J. 2012;23(1):26-9.

21. Wang YT, Haines TP, Ritchie P, Walker C, Ansell TA, Ryan DT, et al. Early mobilization on continuous renal replacement therapy is safe and may improve filter life. Crit Care. 2014;18(4):R161.

22. Genc A, Ozyurek S, Koca U, Gunerli A. Respiratory and Hemodynamic Responses to Mobilization of Critically Ill Obese Patients. Cardiopulm Phys Ther J. 2012;23(1):14-8.

23. Hodgson CL, Stiller K, Needham DM, Tipping CJ, Harrold M, Baldwin CE, et al. Expert consensus and recommendations on safety criteria for active mobilization of mechanically ventilated critically ill adults. Crit Care. 2014;18(6):658.

24. Gosselink R, Bott J, Johnson M, Dean E, Nava S, Norrenberg M, et al. Physiotherapy for adult patients with critical illness: recommendations of the European Respiratory Society and European Society of Intensive Care Medicine Task Force on Physiotherapy for Critically Ill Patients. Intensive Care Med. 2008;34(7):1188-99.

25. Bourdin G, Barbier J, Burle JF, Durante G, PassantS, Vincent $\mathrm{B}$, et al. The feasibility of early physical activity in intensive care unit patients: a prospective observational one-center study. Respir Care. 2010;55(4):400-7.

26. TEAM Study Investigators, Hodgson C, Bellomo R, Berney $\mathrm{S}$, Bailey M, Buhr H, et al. Early mobilization and recovery in mechanically ventilated patients in the ICU: a binational, multi-centre, prospective cohort study. Crit Care. 2015;19(1):81.

27. Nozawa E, Sarmento GJV, Vega JM, Costa D, Silva JEP, Feltrim MIZ. Perfil de fisioterapeutas brasileiros que atuam em unidades de terapia intensiva. Fisioter Pesqui. 2008;15(2):177-82.

28. Bhat A, Chakravarthy K, Rao BK. Mobilization of patients in neurological intensive care units of India: A survey. Indian J Crit Care Med. 2016;20(6):337-41. 
29. Hale C, Wong K, Pennings A, Rnic A, Tobali B, Hawke C, et al. Practice patterns of Canadian physiotherapists mobilizing patients with external ventricular drains. Physiother Can. 2013;65(4):365-73.

30. Green M, Marzano V, Leditschke IA, Mitchell I, Bissett B. Mobilization of intensive care patients: a multidisciplinary practical guide for clinicians. J Multidiscip Healthc. 2016;9:247-56.

31. Harris CL, Shahid S. Physical therapy-driven quality improvement to promote early mobility in the intensive care unit. Baylor Univ Med Cent Proc. 2014;27(3):203-7.

32. McGrane S, Hughes CG, Pandharipande PP. Sedation in the intensive care setting. Clin Pharmacol. 2012;4:53-63.

33. Kamdar BB, Combs MP, Colantuoni E, King LM, Niessen T, Neufeld KJ, et al. The association of sleep quality, delirium, and sedation status with daily participation in physical therapy in the ICU. Crit Care. 2016;20(1):261.

34. Parker A, Sricharoenchai T, Needham DM. Early Rehabilitation in the Intensive Care Unit: Preventing Physical and Mental Health Impairments. Curr Phys Med Rehabil reports. 2013;1(4):307-14.

35. Koo KKY, Choong K, Cook DJ, Herridge M, Newman A, Lo V, et al. Early mobilization of critically ill adults: a survey of knowledge, perceptions and practices of Canadian physicians and physiotherapists. CMAJ Open. 2016;4(3):E448-54.

36. Harrold ME, Salisbury LG, Webb SA, Allison GT. Early mobilisation in intensive care units in Australia and Scotland: a prospective, observational cohort study examining mobilization practises and barriers. Crit Care. 2015;19(1):336.

37. Parry SM, Puthucheary ZA. The impact of extended bed rest on the musculoskeletal system in the critical care environment. Extrem Physiol Med. 2015;4:16.

38. Berney S, Haines K, Skinner EH, Denehy L. Safety and feasibility of an exercise prescription approach to rehabilitation across the continuum of care for survivors of critical illness. Phys Ther. 2012;92(12):1524-35.

39. Sommers J, Engelbert RHH, Dettling-IhnenfeldtD, Gosselink R, Spronk PE, Nollet F, et al. Physiotherapy in the intensive care unit: an evidence-based, expert driven, practical statement and rehabilitation recommendations. Clin Rehabil. 2015;29(11):1051-63.
40. Mendez-Tellez PA, Nusr R, Feldman D, Needham DM. Early Physical rehabilitation in the ICU: A review for the Neurohospitalist. Neurohospitalist. 2012;2(3):96-105.

41. Kho ME, Molloy AJ, Clarke FJ, Ajami D, Mccaughan M, Obrovac K, et al. TryCYCLE : a prospective study of the safety and feasibility of early in-bed cycling in mechanically ventilated patients. PLoS One. 2016;11(12):e0167561.

42. van Willigen Z, Collings N, Richardson D, Cusack R. Quality improvement: The delivery of true early mobilisation in an intensive care unit. BMJ Qual Improv Rep. 2016;5:u211734. w4726.

43. Zomorodi M, Topley D, McAnaw M. Developing a mobility protocol for early mobilization of patients in a surgical/ trauma ICU. Crit Care Res Pract. 2012;2012:964547.

44. Frazzitta G, Zivi I, Valsecchi R, Bonini S, Maffia S, Molatore $\mathrm{K}$, et al. Effectiveness of a very early stepping verticalization protocol in severe acquired brain injured patients: A randomized pilot study in ICU. PLoS One. 2016;11(7):e0158030.

45. Stiller K, Phillips A, Lambert P. The safety of mobilisation and its effect on haemodynamic and respiratory status of intensive care patients. Physiother Theory Pract. 2004;20(3):175-85.

46. Berney S, Haines K, Denehy L. Physiotherapy in critical care in Australia. Cardiopulm Phys Ther J. 2012;23(1):19-25.

47. Araújo DN, Dantas DS, Nascimento RSTR. Efeitos do exercício físico em mulheres com câncer de mama submetidas à radioterapia: uma revisão sistemática. Arq Catarin Med. 2012;41(1):78-82.

48. Associação Brasileira de Medicina Física e Reabilitação Sociedade Brasileira de Ortopedia e Traumatologia. Exercício em pacientes oncológicos: Reabilitação. 2012 [cited 16 May 2019]. Available from: https://tinyurl.com/ yy4umtyh

49. Murakami FM, Yamaguti WP, Onoue MA, Mendes JM, Pedrosa RS, Maida ALV, et al. Functional evolution of critically ill patients undergoing an early rehabilitation protocol. Rev Bras Ter Intensiva. 2015;27(2):161-9.

50. Stiller K. Safety issues that should be considered when mobilizing critically ill patients. Crit Care Clin. 2007;23(1):35-53.

51. Starke RM, Komotar RJ, Connolly ES. Decompressive craniectomy for traumatic intracranial hypertension. Neurosurgery. 2017;80(3):N10-1. 
52. Needham DM, Wozniak AW, Hough CL, Morris PE, Dinglas VD, Jackson JC, et al. Risk factors for physical impairment after acute lung injury in a national, multicenter study. Am J Respir Crit Care Med. 2014;189(10):1214-24.

53. Mehrholz J, Thomas S, Burridge JH, Schmidt A, Scheffler B, Schellin R, et al. Fitness and mobility training in patients with Intensive Care Unit-acquired muscle weakness (FITonICU): study protocol for a randomised controlled trial. Trials. 2016;17(1):559.

54. Routsi C, Gerovasili V, Vasileiadis I, Karatzanos E, Pitsolis T, Tripodaki ES, et al. Electrical muscle stimulation prevents critical illness polyneuromyopathy: a randomized parallel intervention trial. CritCare. 2010;14(2):R74.

55. Karatzanos E, Gerovasili V, Zervakis D, Tripodaki ES, Apostolou K, Vasileiadis I, etal. Electrical muscle stimulation: An effective form of exercise and early mobilization to preserve muscle strength in critically Ill patients. Crit Care Res Pract. 2012;2012:432752.

56. Eggmann S, Verra ML, Luder G, Takala J, Jakob SM. Effects of early, combined endurance and resistance training in mechanically ventilated, critically ill patients: a study protocol for a randomised controlled trial. Trials. 2016;17:403.
57. Santos LJ, Lemos FA, Bianchi T, Sachetti A, Dall'Acqua AM, Naue WS, et al. Early rehabilitation using a passive cycle ergometer on muscle morphology in mechanically ventilated critically ill patients in the Intensive Care Unit (MoVe-ICU study): study protocol for a randomized controlled trial. Trials. 2015;16:383.

58. Mateo RJN, Laínez MGL. Anemia do atleta (I): fisiopatologia do ferro. Rev Bras Med Esporte. 2000;6(3):108-14.

59. Böhn J, Monteiro MB, Thomé FS. Efeitos do exercício aeróbio durante a hemodiálise em pacientes com doença renal crônica: uma revisão da literatura. J Bras Nefrol. 2012;34(2):189-94.

60. Silva SF, Pereira AA, Silva WAH, Simões R, Barros Neto JR. Physical therapy during hemodialyse in patients with chronic kidney disease. J Bras Nefrol. 2013;35(3):170-6.

61. Moura RMF, Silva FCR, Ribeiro GM, Souza LA. Effects of physical exercise during hemodialysis in patients with chronic renal insufficiency: a literature review. Fisioter Pesqui. 2008;15(1):86-91.

62. Cesar F, Marcucci I. O papel da fisioterapia nos cuidados paliativos a pacientes com câncer. Cancerologia. 2005;51(1):67-77.

63. Hoyer EH, Brotman DJ, Chan KS, Needham DM. Barriers to early mobility of hospitalized general medicine patients: survey development and results. Am J Phys Med Rehabil. 2015;94(4):304-12.

Received: 08/16/2019

Recebido: 16/08/2019

Approved: 04/16/2020

Aprovado: $16 / 04 / 2020$ 